\title{
EFFECT OF SOME NATURAL PRODUCTS AND METRONIDAZOLE ON IMMUNITYAGAINST ENTAMOEBA HISTOL YTICA INFECTION IN MICE
}

\author{
By \\ MOHAMED FATHY ABOUEL-NOUR ${ }^{1^{*}}$, SHADIA FARID HAMADA ${ }^{1}$ \\ AND SUHA JAWAD KADHIM ${ }^{2}$
}

Department of Zoology, Faculty of Science, Mansoura University ${ }^{1}$, Mansoura,

P.O. Box 35516, Dakahlia, Egypt and Senior Biology, Scientific Adviser Bureau, Ministry of Industry and Minerals ${ }^{2}$, Iraq ( ${ }^{*}$ Correspondence:abouelnour@hotmail.com)

\section{Abstract}

The present study evaluated the efficacy of Garlic, Mirazid ${ }^{\circledR}$, Ginger as well as Metronidazole ${ }^{\circledR}$ in treating mice experimentally infected with $E$. histolytica cysts. The results showed that all mice infected with E. histolytica cysts and treated with Garlic, Mirazid, Ginger and Metronidazole were significant improved as indicated by the stool analysis and alteration in the immune response by the levels of cytokines IL-5 \& IFN- $\gamma$.

Key words: Entamoeba histolytica, Mice, Garlic, Mirazid, Ginger, Metronidazole, IL-5, IFN- $\gamma$.

\section{Introduction}

Entamoeba histolytica, an enteric protozoan, is a well-established causative agent of amoebic dysentery. It has a high potential for invading and destroying human tissue. The parasite lives in the human gut in an environment of reduced oxygen pressure, and during tissue invasion it gets exposed to reactive oxygen species such as superoxide radical anions and hydrogen peroxide (Sen et al, 2007). Only some species of Entamoe$b a$ are known to be potential pathogen and harmful, for example: the E. histolytica (Schaudinn, 1903) sometimes invade the tissue of man and cause about 50 million cases of infections up to 100000 deaths per year worldwide (Hamzah et al, 2006). Both Entamoeba histolytica and Entamoeba dispar are two morphologically indistinguishable human protozoa parasites that are genetically distinct species (Al-Braiken and Salem, 2008). Chemotherapy against Entamoeba was well established by both synthetic and natural products (Gundamaraju et al, 2015). On the other hand, the outcome predicts of Th1 \& Th2 cytokines act as a well regulated mechanism for an effective control of E. histolytica infection (Tessema et al, 2009).

The present study aimed to investigate the effectiveness of Garlic (Allium sativum), Mirazid $^{\circledR}$ (Commiphora molmol) and Ginger (Zingbar officinale), as natural medicinal components in treatment of Entamoeba histolytica in experimentally infected immune competent mice as compared the efficacy of a medical component Meteronidazol ${ }^{\circledR}$. Although the role of cytokines in parasitic infections was widely studied in animal models, but with few works on the importance of Th1 cytokine IFN-gamma (IFN- $\gamma$ ) and Th2 cytokine interleukin-5 (IL-5) and in human amoebiasis histolytica.

\section{Materials and Methods}

Male Swiss Albino mice animals were used in this work, weighing 25-30grams, they were from three to five weeks in age. They were housed in well ventilated cages with perforated covers, supplied with standard pellet food and water. Bedding was changed every day. The mice were allowed to adapt to the laboratory environmental conditions for one week before experimented with (El-Fakhry et al, 1998). The mice stools were examined by direct wet saline smear, iodine and Sheather's sugar flotation method to exclude the parasites (El-Naggar et al, 2006).

Entamoeba histolytica cysts were prepared from stool of an infected patient and the cysts were isolated (Khairnar and Parija, 2007) shortly as follows: 1- Stool sample was diluted by distilled water (1:10). 2- Filtered through four layers of gauze. $3-2 \mathrm{ml}$ of the filtrate was added to $2 \mathrm{ml}$ of the Phosphate-buffered saline (PBS). 4- Centrifugation at $2000 \mathrm{rpm} / \mathrm{min}$ for five minutes at room temperature. 5- Precipitate was discarded and filtrate was diluted with distilled water (1:10). 6- Diluted filtrate was used for 
orally administration of E. histolytica cysts to the mice.

Experimental design: clean laboratory breed male Swiss Albino mice were divided into four groups of 5 mice each as follows: Uninfected untreated control group: mice were neither treated nor infected. Infected untreated group: mice were infected orally as $10^{4}$ E. histolytica cysts/mouse (Gaafar, 2007) using a gastric gavage with 23-guage needle tips with plastic tubing (Riad et al, 2009). The other groups were divided into two subgroups: Prophylactic group: mice were subdivided as follows: a- Prophylactic (Subgroup I or P1): mice received garlic two days before infection and continued on garlic daily for 12 days post-infection. bProphylactic 2 (Subgroup II or P2): mice received ginger two days before infection and continued on ginger daily for 12 days post-infection. c- Prophylactic 3 (Subgroup III or P3): the mice received mirazid two days before infection and continued on daily for 12 days post-infection. d- Prophylactic 4 (Subgroup IV or P4): mice received metronidazole two days before infection and continued on metronidazole daily for 12 days post-infection. Therapeutic group: mice were subdivided into subgroups: a- Treated 1 (Subgroup I or T1): mice received garlic one day post-infection and continued on garlic daily for 14 more days. b- Treated 2 (Subgroup II or T2): mice received ginger one day post-infection and continued on ginger daily for 14 more days. c- Treated 3 (Subgroup III or T3): mice received mirazid one day post-infection and continued on mirazid daily for 14 more days. d- Treated 4 (Subgroup IV or T4): mice received metronidazole one day post-infection and continued on metronidazole daily for 14 days.

Infection was done by oral inoculation of E. histolytica $10^{4}$ cysts/ mouse; using gastric gavage, with plastic tubing and a 23-gauge needle ( $\operatorname{Riad}$ et al, 2009).

Garlic dose was calculated as $50 \mathrm{gm} / \mathrm{kg}$ body weight/day. Each mouse was given 0.5 $\mathrm{ml}$ of garlic an hour before breakfast. Preparation of garlic solution: Fresh garlic bulbs were peeled, washed with distilled water, and then left to dry. After drying, about 500gms were crushed using a blender until become a paste. The formed paste was diluted with distilled water forming a solution of $1 \mathrm{gm} / \mathrm{ml}$, equal assemblies and then stored at $-20^{\circ} \mathrm{C}$ until use (Masamha et al, 2010).

Ginger was calculated as $50 \mathrm{gm} / \mathrm{kg}$ body weight/day. Stock solution: $88 \mathrm{gm}$ in $35 \mathrm{ml}$. Each mouse was given $0.006 \mathrm{ml}$ completed with distilled water to $0.5 \mathrm{ml}$ daily, an hour before breakfast (Burke et al, 2009).

Mirazid was calculated as $10 \mathrm{gm} / \mathrm{kg}$ body weight/day. Stock solution: Each mouse was given $0.006 \mathrm{ml}$ of Mirazid emulsion solution completed with dist. water to $0.5 \mathrm{ml}$ daily, an hour before breakfast (Hegab and Hassan, 2003).

Metronidazole was calculated as $50 \mathrm{gm}$ of Metronidazole/ kg body weight/ day. Each mouse was given $0.006 \mathrm{ml}$ of Metronidazole solution completed with dist. water to $0.5 \mathrm{ml}$ daily, an hour before breakfast (Iyer et al, 2014).

Stool analysis: Stool analysis was done for all groups every two days as collected and stained and checked by light microscope (Kuk et al, 2012).

Assessment of IFN- $\gamma$ level in mice sera: IFN- $\gamma$ level was measured by QuantikineMIF00 mouse IFN- $\gamma$ ELISA immunoassay kit from R\&D (Minneapolis, MN, USA) following the manufacturer's instructions.

Blood samples were collected from mice, left at room temperature to sediment and then centrifuged at $2000 \mathrm{xg}$ for 20 minutes. The labeled sera samples were kept at $-20^{\circ} \mathrm{C}$ until used.

The IL-5 level was measured by mouse IL-5 ELISA immunoassay kit from RayBio $^{\circledR}$ Company, following the manufacturer's instructions.

Statistical analysis: Data were analyzed by using the Microsoft Excel 2007 Software and descriptive statistics were presented as counts and percentages. Chi-square tests and Fisher's exact test were used to assess the significance of the observed associations and a significant level of 0.05 was adopted for all tests (Kirkwood, 1992).

\section{Results}

The results are shown in tables $(1,2,3,4$, $5,6 \& 7)$. 
Table 1: Stool analysis of all used micegroups.

\begin{tabular}{|c|c|c|c|c|c|c|c|c|c|c|}
\hline \multirow{2}{*}{ Date collected } & \multirow{2}{*}{$\begin{array}{c}\text { Control } \\
+\mathrm{ve}(\mathrm{Gp} 2)\end{array}$} & \multirow{2}{*}{$\begin{array}{c}\text { Control } \\
\text {-ve (GP1) }\end{array}$} & \multicolumn{4}{|c|}{ Prophylactic } & \multicolumn{4}{|c|}{ Experimental } \\
\hline & & & GIIa1 & GIIb1 & GIIc1 & GIId1 & GIIa2 & GIIb2 & GIIc2 & GIId2 \\
\hline A wk. before infection & -ve & -ve & -ve & -ve & -ve & -ve & -ve & -ve & -ve & -ve \\
\hline 2 days before infection & -ve & -ve & -ve & -ve & -ve & -ve & -ve & -ve & -ve & -ve \\
\hline 2 days post infection & -ve & $+\mathrm{ve}$ & $+\mathrm{ve}$ & -ve & $+\mathrm{ve}$ & $+\mathrm{ve}$ & $+\mathrm{ve}$ & -ve & $+\mathrm{ve}$ & $+\mathrm{ve}$ \\
\hline 4 d days post infection & -ve & $+\mathrm{ve}$ & $+\mathrm{ve}$ & -ve & $+\mathrm{ve}$ & $+\mathrm{ve}$ & $+\mathrm{ve}$ & -ve & $+\mathrm{ve}$ & $+\mathrm{ve}$ \\
\hline 6 days post infection & -ve & $+\mathrm{ve}$ & $+\mathrm{ve}$ & $+\mathrm{ve}$ & $+\mathrm{ve}$ & $+\mathrm{ve}$ & $+\mathrm{ve}$ & $+\mathrm{ve}$ & $+\mathrm{ve}$ & $+\mathrm{ve}$ \\
\hline 8 days post infection & -ve & $+\mathrm{ve}$ & $+\mathrm{ve}$ & $+\mathrm{ve}$ & -ve & -ve & $+\mathrm{ve}$ & $+\mathrm{ve}$ & $+\mathrm{ve}$ & $+\mathrm{ve}$ \\
\hline 10 days post infection & -ve & $+\mathrm{ve}$ & $+\mathrm{ve}$ & $+\mathrm{ve}$ & -ve & -ve & $+\mathrm{ve}$ & -ve & $+\mathrm{ve}$ & $+\mathrm{ve}$ \\
\hline 12 days post infection & -ve & $+\mathrm{ve}$ & -ve & -ve & -ve & -ve & -ve & -ve & -ve & -ve \\
\hline 14 days post infection & -ve & $+\mathrm{ve}$ & -ve & -ve & -ve & -ve & -ve & -ve & -ve & -ve \\
\hline 16 days post infection & $-\mathrm{ve}$ & $+\mathrm{ve}$ & $-\mathrm{ve}$ & $-\mathrm{ve}$ & $-\mathrm{ve}$ & $-\mathrm{ve}$ & $-\mathrm{ve}$ & $-\mathrm{ve}$ & $-\mathrm{ve}$ & $-\mathrm{ve}$ \\
\hline
\end{tabular}

Administration of cysts in infected non treated group produced a significant increase $(\mathrm{P}<0.05)$ in the level of serum IFN- $\gamma$ of this group when compared with the level of IFN$\gamma$ in uninfected non treated control group. In groups infected and treated as Garlic (P1), Ginger (P2), Mirazid (P3) and Metronidazole $(\mathrm{P} 4)$ protected groups; there was a significant decrease $(\mathrm{P}<0.05)$ in serum levels

Table 2: Mean IFN- $\gamma$ concentrations in protected groups in comparison with +ve (infected) and -ve (uninfected) controls.

\begin{tabular}{|l|c|c|c|c|c|c|}
\hline Variant & Control -ve (GP1) & Control +ve (GP2) & P1 & P2 & P3 & P4 \\
\hline Mean & 126.7 & 800.8 & 180 & 207.8 & 231.8 & 268.3 \\
\hline SE \pm & $0.6^{\mathrm{b}}$ & $1.5^{\mathrm{a}}$ & $1.1^{\mathrm{ab}}$ & $0.8^{\mathrm{ab}}$ & $1.4^{\mathrm{ab}}$ & $1.2^{\mathrm{ab}}$ \\
\hline SD & 1.4 & 3.3 & 2.6 & 1.7 & 3.1 & 2.6 \\
\hline
\end{tabular}

$\mathrm{a}=$ significant value when compared with - ve control $(\mathrm{P}<0.05), \mathrm{b}=$ significant value when compared with $+\mathrm{ve}$ control $(\mathrm{P}<$ $0.05)$, no significant difference $(\mathrm{P}>0.05)$ when means superscripts with same letters.

Table 3: Mean IFN- $\gamma$ concentrations in treated groups compared with +ve and -ve controls.

\begin{tabular}{|l|c|c|c|c|c|c|}
\hline Variant & Control -ve (GP1) & Control +ve (Gp2) & T1 & T2 & T3 & T4 \\
\hline Mean & 126.7 & 800.8 & 205.4 & 168.8 & 165 & 235.8 \\
\hline $\mathrm{SE} \pm$ & $0.6^{\mathrm{b}}$ & $1.5^{\mathrm{a}}$ & $0.7^{\mathrm{ab}}$ & $0.7^{\mathrm{ab}}$ & $0.8^{\mathrm{ab}}$ & $1.4^{\mathrm{ab}}$ \\
\hline $\mathrm{SD}$ & 1.4 & 3.3 & 1.6 & 1.6 & 1.9 & 3.2 \\
\hline
\end{tabular}

Table4: Mean IFN- $\gamma$ concentrations in protected and treated groups compared with +ve and -ve controls

\begin{tabular}{|l|l|l|l|l|l|l|l|l|l|l|}
\hline Variant & Control -ve (GP1) & Control +ve (Gp2) & P1 & P2 & P3 & P4 & T1 & T2 & T3 & T4 \\
\hline Mean & 126.7 & 800.8 & 180 & 207.8 & 231.8 & 268.3 & 205.4 & 168.8 & 165 & 235.8 \\
\hline SE \pm & $0.6^{\mathrm{b}}$ & $1.5^{\mathrm{a}}$ & $1.1^{\mathrm{ab}}$ & $0.8^{\mathrm{ab}}$ & $1.4^{\mathrm{ab}}$ & $1.2^{\mathrm{ab}}$ & $0.7^{\mathrm{ab}}$ & $0.7^{\mathrm{ab}}$ & $0.8^{\mathrm{ab}}$ & $1.4^{\mathrm{ab}}$ \\
\hline SD & 1.4 & 3.3 & 2.6 & 1.7 & 3.1 & 2.6 & 1.6 & 1.6 & 1.9 & 3.2 \\
\hline
\end{tabular}

Data represented by mean \pm SE of the 5 - mice group, where a letter represent a significant value when compared with uninfected group $(\mathrm{P}<0.05)$. And b letter stand as a significant value when compared with infected group $(\mathrm{P}<0.05)$.

Administration of cysts in infected non treated group produced a significant decrease $(\mathrm{P}<0.05)$ in serum IL-5 level as compared with the level of IL-5 in negative control group. In the protected prophylactic groups infected and treated as Ginger (P2), Mirazid (P3), Garlic (P1) and Metronidazole (P4) protected groups; there was a significant increase in levels of IL-5 as comparedwith positive control.

Table 5: Mean IL-5 concentrations in protected groups compared with +ve and -ve controls.

\begin{tabular}{|l|l|l|l|l|l|l|}
\hline Variant & Control -ve (GP1) & Control +ve (GP2) & P1 & P2 & P3 & P4 \\
\hline Mean & 182 & 95.3 & 155 & 143 & 145 & 173.5 \\
\hline SE \pm & $6^{\mathrm{b}}$ & $0.9^{\mathrm{a}}$ & $1.6^{\mathrm{ab}}$ & $4^{\mathrm{ab}}$ & $3.7^{\mathrm{ab}}$ & $0.5^{\mathrm{b}}$ \\
\hline SD & 13.4 & 2 & 3.5 & 8.9 & 8.3 & 1.1 \\
\hline
\end{tabular}

Comparing Ginger, Mirazid and Garlic protected group with negative control group showed a significant decrease. In Metronidazole (T4), Garlic (T1) \& Mirazid (T3) gave a significant increase in IL-5 level as compared with positive control, but, a significant decrease in levels of IL-5 in Ginger (T2), Mirazid (T3) and Garlic (T1) treated groups as compared to negative control one. 
Table 6: Mean IL-5 concentrations in treated groups compared with +ve and -ve controls.

\begin{tabular}{|l|l|l|l|l|l|l|}
\hline Variant & Control -ve (GP1) & Control +ve (GP2) & T1 & T2 & T3 & T4 \\
\hline Mean & 182 & 95.3 & 170 & 103 & 141 & 175 \\
\hline SE \pm & $6^{\mathrm{b}}$ & $0.9^{\mathrm{a}}$ & $5.1^{\mathrm{ab}}$ & $0.8^{\mathrm{a}}$ & $1.1^{\mathrm{ab}}$ & $1.7^{\mathrm{b}}$ \\
\hline SD & 13.4 & 2 & 11.3 & 1.9 & 2.5 & 3.7 \\
\hline
\end{tabular}

Table 7: Main levels of serum IL-5 cytokine in mice serum of groups.

\begin{tabular}{|l|l|l|l|l|l|l|l|l|l|l|}
\hline Variant & Control -ve (GP1) & Control +ve (GP2) & P1 & P2 & P3 & P4 & T1 & T2 & T3 & T4 \\
\hline Mean & 182 & 95.3 & 155 & 143 & 145 & 173.5 & 170 & 103 & 141 & 175 \\
\hline SE \pm & $6^{\mathrm{b}}$ & $0.9^{\mathrm{a}}$ & $1.6^{\mathrm{ab}}$ & $4^{\mathrm{ab}}$ & $3.7^{\mathrm{ab}}$ & $0.5^{\mathrm{b}}$ & $5.1^{\mathrm{ab}}$ & $0.8^{\mathrm{a}}$ & $1.1^{\mathrm{ab}}$ & $1.7^{\mathrm{b}}$ \\
\hline SD & 13.4 & 2 & 3.5 & 8.9 & 8.3 & 1.1 & 11.3 & 1.9 & 2.5 & 3.7 \\
\hline
\end{tabular}

Data represented by mean \pm SE of the 5 - mice group, where a letter represent a significant value when compared with uninfected group $(\mathrm{P}<0.05)$. And $\mathrm{b}$ letter stand as a significant value when compared with infected group $(\mathrm{P}<0.05)$. While no significant difference $(\mathrm{P}>0.05)$ when means superscripts with same letters.

\section{Discussion}

In the present study, treated prophylactic and experimental groups showed all negative results by day nine post infection for all the treatment types. These negative results indicate that all the treatment therapy used in this experiment such as Ginger, Garlic, Mirazid and Metronidazole were all effective in removing and clearing the trophozoites and cysts from the intestine and all body of experimental mice as there were no signs of infection in the feces while the positive control infective group still showing positive results in having the infection by passing the cysts in the feces, and they were still showing positive results till day 15 of the experiment.

No doubt, E. histolytica inhabits the lumen of the large intestine, initiating a response in the immune system in order to overcome and eliminate the infection, that is shown to be done through the secretion of some cytokine mediators and immunoglobulins that cause the indirect production and activation of some factors that deal directly with the parasite to contain and eliminate its danger and removal from the body. These cytokines have a great role in dealing with the parasites regardless the very small quantities produced against the presence of E. histolytica cyst (Asgharpour et al, 2005).

In the present study, IFN- $\gamma$ level increased significantly in mice sera of infected untreated positive control group when compared with negative control group (uninfected untreated). In the experimental groups (both protected (prophylaxis) and treated) there were significant decrease in IFN- $\gamma(\mathrm{P}<$ $0.05)$ in all groups: garlic (P1, T1), ginger
$(\mathrm{P} 2, \mathrm{~T} 2)$, mirazid (P3, T3) metronidazole $(\mathrm{P} 4, \mathrm{~T} 4)$, when compared to the infected non treated positive control group. In groups P1 $\&$ T1, garlic showed significant increase in the IFN- $\gamma$ level as compared to the negative control. In the current study, there was increase in the level IFN- $\gamma$ cytokine in the group of infected mice when it was compared to uninfected control mice group, suggesting that the immune system of the infected mice was aiming to overcome and remove the infection by secreting cytokines as it was shown from the above IFN- $\gamma$ results obtained in the current work. From the increased secretion of the IFN- $\gamma$ cytokine as an immune mediator during the infection with E. histolytica, that indicates that the immune response to this infection is mainly a Th1 type response. The present agreed with McDonald (2000). Some cytokines could permit Th1 cells to be effective in protection against parasitic intracellular infections, such as infection by Cryptosporidium parvum parasite (Lean et al, 2002; Petry et $a l, 2010)$. IFN- $\gamma$ played a very effective role in the innate and adaptive immune responses to Cryptosporidium parvum infection but the mechanism is not well known (Aliberti et al, 1996). Also, IFN- $\gamma$ played a very important role in host resistance against infection with Trypanosoma cruzi (Cardillo et al, 1996). In infected groups, the level of IFN- $\gamma$ was increased significantly as a response to the infection with E. histolytica. Again, the synergism between Th1 (to control parasite growth and activity) and Th2 cytokines (to minimize pathology) is in agreement with those results reported by other authors (Tessema et al, 2009). 
In the present study, IL-5 level decreased significantly in infected untreated positive control group when compared with negative control group (uninfected untreated). In the experimental groups, there was significant increase in IL-5 $(\mathrm{P}<0.05)$ in all the groups as compared to the positive control group. $\mathrm{P} 1, \mathrm{P} 3$, and $\mathrm{P} 4$ protected groups showed significant decrease in the level of IL-5 when compared to the negative control group (uninfected untreated). In the experimental groups (infected treated) there were significant increase in IL-5 $(\mathrm{P}<0.05)$ in groups: mirazid (T3) and metronidazole (T4), when compared to the infected non treated positive control group. In garlic group (T1) treated showed significant decrease in the level of IL-5 when compared to the negative control group (uninfected untreated). In ginger group (T2) treated showed significant increase in the level of IL-5 when compared to the positive control group (infected untreated). Alterations in the immunological parameters in infection with parasites were reported by many authors as an example the level of IL-5 was increased with parasite infection (Faccioli et al, 1997). There was statistically significant increase in IL-5 levels in Giardia lamblia infected patients (Matowicka-Karna et al, 2009). The levels of IL $-5 \&$ IFN- $\gamma$ showed a highly significant increase in acute form of schistosomiasis mansoni infected patients (de Jesus et al, 2002), and increase in IL-5 \& IL-13 levels as a response to extract of soluble antigen of Onchocerca volvulus (Brattig et al, 2002). Cooper et al. (2001) reported that early $O$. volvulus caused increase production of IL-5 \& IFN- $\gamma$ cytokines by the immune response. Also, in patients with untreated chronic leishmaniasis there was a significant increase in IFN- $\gamma$, IL-5 \& IL-13 levels produced in vitro by peripheral blood mononuclear cells (PBMC), suggested Th1 \& Th2 responses. However, in acute leishmaniasis patients the response was only a Th1 response, as IFN- $\gamma$ level increased and IL-5 \& IL-13 levels decreased (Ajdary et al, 2009). Ishikawa et al. (1998) in mice experimental infection with Trichinella spiralis and Nippostrongylus brasiliensis, found many cyto- kines released from Th1 \&Th2 cells among others IL-5 \& IFN- $\gamma$ involved. Activated Th1 cells produce IFN- $\gamma$ which in turn have a suppressive act on the production and release of IgE. IFN- $\gamma$ initiates and stimulated the intracellular killing of parasites by macrophages after initiating the production of reactive oxygen and secretion of hydrogen peroxide (Lucey et al, 1996). TouilBoukoffa et al. (1997) showed that the defense mechanisms in the infection with echinococcosis include, IL- 6 beside the production of IFN- $\gamma$. Ajami and Rafiei (2007) showed that in Hymenolepis nana infected patients there were an increase in the levels some cytokines such as IL-5, IL-12, IL-13 \& IFN- $\gamma$ cytokines. In the current study, $E$. histolytica showed alteration in IL-5 \& IFN$\gamma$ cytokines levels. In the immune response action, Th1 response work in the direction that the lymphocytes produce IFN- $\gamma$ cytokine that inhibits the proliferation and the action of Th2 immune response cells, so help in the cellular response. While in Th2 response, lymphocytes produce IL-4, IL-5, IL-6, IL-10 \& IL-13 cytokines initiating the humoral response (Diaz-Sanchez, 1997). In the present study, treated infected mice showed a significant increase in IL-5 serum levels, and a significant decrease in IFN- $\gamma$ levels of the treated groups. Wu et al. (2015) stated that inflammatory cytokines produced at the early stages of the malaria infection contribute to shaping protective immunity and pathophysiology. They determined that the cytokine responses by monocytes, macrophages, and dendritic cells (DCs) to purified Plasmodium falciparum and P. berghei ANKA, and by spleen macrophages and DCs from $P$. yoelii 17NXL-infected \& $P$. berghei ANKA-infected mice. They found that monocytes and macrophages did not produce inflammatory cytokines to malaria parasites and that DCs were primary source early in infection, and DC subsets differentially produce cytokines and blocking of phagosomal acidification by inhibiting the vacuolar-type $\mathrm{H}(+)$-ATPase enabled macrophages to elicit cytokine responses. They concluded that the important implications for enhancing the efficacy of a whole para- 
site-based malaria vaccine and for designing strategies for the development of protective immunity to pathogens that induce immune responses primarily through endosomal receptors. Consequently, there was immune response and inflammatory action in parasitosis shown by the release of IFN- $\gamma$, TNF, IL-1b, IL-5 \& IL-13 cytokines.

The present results showed that the immune response in E. histolytica infection in immunocompetent individuals. Significant progresses have been made in the getting to know the host responses against $E$. histolytica that include immune mechanisms that overcome the infection, though still important gaps in the study of all the immune mediators work in that infection control strategies. The current work affords initial information in this immune response against infections with parasites, confirming the role of IFN- $\gamma$ and IL-5 as important cytokines and could be considered as the key cytokines in both arms of immunity mechanisms the innate and the adaptive immunity during the E. histolytica infection (Ankari and Mirelman, 1999). The allicin with its antimicrobial effect was prepared from mincing fresh garlic bulbs smoothly as a paste (Borlinghaus et al, 2014). Choosing the dose of garlic in the current study was based on a previous use by other papers and it was 50 $\mathrm{mg} / \mathrm{kg}$ body weight (Lemar et al, 2002). This dose was equal to the daily recommended to have a good health which means the uptake of about 4 grams daily. In the current study the use of garlic on the experimentally infected mice was completely successful in eradicating the $E$. histolytica trophozoites and cysts from stool. Ginger is considered one of the best and commonly used fresh herbs worldwide (Blumenthal et $a l, 2000)$. The present results agreed with others showed that Ginger proved to a strong and effective against $S$. mansoni (Sanderson et al, 2002), Adewunmi et al. (1990) and also against gastrointestinal nematodes (Iqbal et al, 2006) by the mechanism of killing parasites by binding to parasite beta-tubulin proteins and obstructing glucose uptake. This great effect of Ginger connected to the important anthelmintic activity of its ingre- dients, Gingerol (Lin et al, 2010) and Shogaol (Ali et al, 2008).

In the current study, administration of the ginger to the experimentally infected mice groups significantly fixed the elevation in the inflammatory risk factors, suggesting its possible anti-inflammatory, antioxidant and immunomodulatory abilities. These valuable effects of ginger were also reported previously and was explained and assumed for its active components as Gingerols, Paradol, Shogaols, and Zingerone (Adewusi et al, 1996). Metronidazole is synthetic chemical drug derived from Streptomyces antibiotic Azomycin and was early used in 1960's against trichomoniasis disease and was the first drug used to achieve about $100 \%$ curable rate (Cosar and Julou, 1959). It is a small size molecule not bind to serum proteins, and is well distributed over the tissues and fluids of the body such as brain, blood, bone, pelvic tissue, bile, cerebrospinal fluid, seminal fluid, and pulmonary exudates (Edwards, 1993). Metronidazole could easily penetrate the protozoan parasite $T$. vaginalis by passive diffusion due to its small molecular size. By the anaerobic reduction to the initially inactive drug and the formation of a cytotoxic nitro radical anion that could easily bind to DNA breaking its strands leading to the drug effectiveness in causing cell death.

On the other hand, Mirazid is a natural product extracted herbal tree Commiphora molmol, and is called Myrrh. After isolation from the tree it was extracted by oleo-resin. C. molmol (Myrrh) is an oleo-gum resin obtained from the stem of a medicinal herb, Commiphora molmol (Family: Burseraceae), a tree grown in northeast of Africa and Arabian Peninsula (Wallis, 1967). Observations of the efficacy of Mirazid ${ }^{\circledR}$ oleoresin and myrrh volatile oil indicated that both products showed dose-dependent anthelmintic efficacy with the anterior half of the fluke consistently more severely affected than the posterior half. Scanning electron microscopy could be used to determine the target of the tested products, as morphological changes in tegumental surface could be observed. These changes consisted of swelling, blebbing, 
which was later disrupted, leading to erosion and desquamation of the tegument, resulting in the lesion, and finally the exposure and disruption of basal lamina and the dislodging of spines. Swelling and blebbing were characteristic of a stress response by the fluke; they had been seen in the present study with TCBZ-SO and in previous studies with other drugs as Clorsulon, Albendazole, Closantel, Nitroxynil, compound alpha, and Artemether (Meaney et al, 2003; McConville et al, 2009). The safety and effectiveness of Myrrh was reported against human schistosomiasis (Massoud et al, 1998; 2000; Gaballah et al, 2001a; El Baz et al., 2003), against human (Motawea et al, 2001; Massoud et al, 2001b,c; Abo-Madyan et al, 2004) and animal fascioliasis (Haridy et al, 2003), dicrocoeliasis dendriticum in man and animals (Massoud et al, 2003) and three liver parasites of edible animals (Morsy et al, 2005; Haridy et al, 2006). Also, Mirazid proved to be anti-nematode in strongyloidiasis stercoralis (Massoud et al, 2006), and anti-protozoa activity in zoonotic C. parvum (Massoud et al, 2008). Also, it has a molluscicidal activity against the Egyptian snail-vectors of Schistosoma haematobium and S. mansoni and Fasciola gigantica (Massoud et al, 2000; Allam et al, 2001; El-Shazly et al, 2001). Also, Mirazid treated the hepatic coccidiosis due to Eimeria stidae in experimentally infected rabbits (Baghaddi and Al-Mathal, 2010). In Saudi Arabia, Mecca Mur or Myrrh was successfully used in treatment of human fascioliasis (Al Mathal and Fouad, 2005) and animal fascioliasis (Abo-Zenadah, 2005) and against dicrocoeliasis dendriticum in man and animals (Al-Mathal and Fouad, 2004) as well as against Biomphalaria arabica (snail vector of S. mansoni in Saudi Arabia), adults and egg masses and fecundity (Al-Mathal and Fouad, 2006). Moreover, Mirazid safely treated zoonotic Bertiella studeri (Al-Mathal et al, 2010)

On the other hand, Abouel-Nour et al. (2015) in experimentally infected Albino mice studied the occurrence of immune and inflammatory responses in Cryptosporodium parvum invasion, when IFN- $\gamma$, TNF, IL- $1 b$,
IL-5 \& IL-13 were released. The immune response elevation clarified infection posttreatment which elevated the pattern of cytokine release levels in comparison with the uninfected and infected controls. The best efficacy in descending was Ginger, Metronidazole, Mirazid and Garlic respectively.

\section{Conclusion}

The outcome data showed that the immune response was elevated in a way to clear the infection using the treatment strategies which appear to elevate the release of cytokines and the alteration in their levels in the serum when compared to the mice with no infection (negative control group) and to the mice infected with the parasite cyst but without treatment (positive control group), from the results obtained after analyzing the stool pictures for all the groups studied and from the immune response investigation using the two effective and important cytokines that play a crucial roles in infection and inflammation and representing both Th1 (IFN- $\gamma$ ) \& Th2 (IL-5) immune response mechanisms, the protocols used were very effective and arranged as follow: ginger, metronidazole, mirazid, garlic respectively according to their best effect on removing the infection and elevation of the immune response.

\section{References}

Abo-Madyan, AA, Morsy, TA, Motawea, SM, Morsy, ATA, 2004: Clinical trial of Mirazid ${ }^{\circledR}$ in treatment of human fascioliasis in Ezbet ElBakly (Tamyia Center) Al-Fayoum Governorate. J. Egypt. Soc. Parasitol. 34, 3: 807-18.

Abouel-Nour, MF, El-Shewehy, DMM, Hamada, SF, Morsy, TA, 2015: The Efficacy of three medicinal plants: garlic, ginger and mirazid and a chemical drug metronidazole against Cryptosporidium parvum. 1- Immunological response. J. Egypt. Soc. Parasitol. 45, 3:559-70.

Abo-Zenadah, NY, 1999: Natural dicrocoeliasis in imported sheep, Jeddah, Saudi Arabia. J. Egypt. Soc. Parasitol. 29, 2:649-52.

Abo-Zenadah, NY, 2005: Treatment of sheep fascioliasis with Mecca Mur. J. Egypt. Soc. Parasitol. 35, 1:363-4.

Adewunmi, CO, Oguntimein, BO, Furu, P, 1990: Molluscicidal and antischistosomal activities of Zingiber officinale. Planta Med. 56:374-6. 
Adewusi, OI, Nix, NA, Lu, X, Colley, DG, Secor, WE, 1996: Schistosoma mansoni: relationship of tumor necrosis factor-alpha to morbidity and collagen deposition in chronic experimental infection. Exp. Parasitol. 84:115-23.

Ajami, A, Rafiei, A, 2007: Cytokine production in Hymenolepis nana infection. Iran. J. Immunol. 4: 236-40.

Ajdary, S, Riazi-Rad, F, Alimohammadian, MH, Pakzad, SR, 2009: Immune response to Leishmania antigen in anthroponotic cutaneous leishmaniasis. J. Infect. 59, 2:139-43.

Al-Braiken, FA, Salem, HS, 2008: Diagnosis of Entamoeba histolytica in symptomatic children, Jeddah City, Saudi Arabia. Egypt. J. Immunol. 15, 1:85-92.

Al Mathal, EM, Fouad, MAH, 2004: Myrrh (Commiphora molmol) in treatment of human and sheep dicrocoeliasis dendriticum in Saudi Arabia. J. Egypt. Soc. Parasitol., 34, 2:713-20.

Al Mathal, EM, Fouad, MAH, 2005: Human fascioliasis among immigrant workers in Saudi Arabia. J. Egypt. Soc. Parasitol. 35, 3:S1199207.

Al Mathal, EM, Fouad, MAH, 2006: Effect of Commiphora molmol on adults, Egg masses and egg-deposition of Biomphalaria arabica under laboratory conditions. J. Egypt. Soc. Parasitol. 36, 1:305-14.

Al-Mathal, EM, Saleh, NMK, Morsy, TA, 2010: Human infection with Bertiella studeri (Cestode: Anoploocephalidae) in an Egyptian worker retuning back from Saudi Arabia. J. Egypt. Soc. Parasitol. 40, 1:89-92.

Ali, IK, Hossain, MB, Roy, S, Ayeh-Kumi, PF, Petri, WA, et al, 2003: Entamoeba moshkovskii infections in children, Bangladesh. Emerg. Infect. Dis. 9:580-4.

Ali, SS, Kasoju, N, Luthra, A, Singh, A, Sharanabasava, $\mathrm{H}$, et al, 2008: Indian medicinal herbs as sources of antioxidants. Food Res. Inter. 41: \1-15.

Aliberti, JC, Cardoso, MA, Martins, GA, Gazzinelli, RT, Vieira, LQ, Silva, JS, 1996: Interleukin-12 mediates resistance to Trypanosoma cruzi in mice and is produced by murine macrophages in response to live trypomastigotes. Infect. Immun. 64:1961-7.

Allam, AF, El-Sayed, MH, Khalil, SS, 2001: Laboratory assessment of the molluscicidal activity of Commiphora molmol (Myrrh) on Biomphalaria alexandrina, Bulinus trunca-tus and Lymnaea cailliaudi. J. Egypt. Soc. Parasitol. 31, 3:683-90.

Ankri, S, Mirelman D, 1999: Antimicrobial properties of allicin from garlic. Microbiol. Infe- ct. J., 1: 125-9.

Asgharpour, A, Gilchrist, C, Baba, D, Hamano, S, Houpt, E, 2005: Resistance to intestinal Enta-moeba histolytica infection is conferred by innate immunity and Gr-1+cells. Infect. Immunol. 73:4522-9.

Baghaddi, HB, Al-Mathal, EM, 2010: Anti-coccidial effect of Commiphora molmol in the domestic rabbet (Oryctolagus cuniculus domesticus). J. Egypt. Soc. Parasitol. 40, 3:653-68.

Blumenthal, M, Goldberg, A, Brinckmann, J, editors, 2000: Herbal Medicine: Expanded Commission E Monographs. Boston (MA): Integrative Medicine Communications.

Borlinghaus, J, Albrecht, F, Gruhlke, MC, Nwachukwu, ID, Slusarenko, AJ, 2014: Allicin: chemistry and biological properties. Molecules 19, 8:12591-618

Brattig, NW, Lepping, B, Timmann, C, et al, 2002: Onchocerca volvulus- exposed persons fail to produce interferon-gamma in response to $O$. volvulus antigen but mount proliferative responses with interleukin-5 and IL-13 production that decrease with increasing microfilarial density. J. Infect. Dis. 185:1148-54.

Cardillo, F, Voltarelli, JC, Reed, SG, Silva, JS, 1996: Regulation of Trypanosoma cruzi infection in mice by gamma interferon and interleukin 10: role of NK cells. Infect. Immunol. 64:128-34.

Cooper, PJ, Mancero, T, Espinel, M, et al, 2001: Early human infection with Onchocerca volvulus is associated with an enhanced parasitespecific cellular immune response. J. Infect. Dis. 183:1662-8.

Cosar, C, Julou, L, 1959: Activity of 1-(2-hydroxyethyl)-2-methyl-5-nitroimidazole (8823 RP) against experimental Trichomonas vaginalis infection. Ann. Inst. Pasteur 96:238-41.

de Jesus, AR, Silva, A, Santana, LB, et al, 2002: Clinical and immunological evaluation of 31 patients with acute Schistosomiasis mansoni. J. Infect. Dis. 185:98-105.

Diaz-Sanchez, D, 1997: The roleof dieselexhaust particles and their associated polyaromatic hydrocarbons in the induction of allergic airway disease. Allergy 52, 38:S52-8.

Edwards, DI, 1993: Nitroimidazole drugs action and resistance mechanisms: Two mechanisms of resistance. J. Antimicrob. Chemother. 31:201-10.

El Baz, MA, Morsy, TA, El Bandary, MM, Motawea, SM, 2003: Clinical and parasitological studies on the efficacy of Mirazid ${ }^{\circledR}$ in treatment of Schistosoma haematobium in Tatoon, Etsa Center, El-Fayoum Governorate. J. Egypt. 
Soc. Parasitol. 33, 3:761-76.

El-Fakhry, Y, Achbarou, A, Desportes, I, Mazier, D, 1998: Encephalitozoon intestinalis: $\mathrm{Hu}-$ moral responses in interferon-gamma receptor knockout mice infected with a Microsporidium pathogenic in AIDS patients. Exp. Parasitol. 89: 113-21.

El-Naggar, SM, El-Bahy, MM, Abd Elaziz, J, El-Dardiry, MA, 2006: Detection of protozoal parasites in the stools of diarrhoeic patients using different techniques. J. Egypt. Soc. Parasitol. $36,1: 7-22$.

El-Shazly, AM, Motawea, SM, El-Gilany, A, Salama, O, Massoud, AM, et al, 2001: Preliminary study of the molluscicidal action of Myrrh. J. Environ. Sci. 21:153-62.

Faccioli, LH, Vargaftig, BB, Medeiros, A, Malheiros, A, 1997: Cytokines in the modulation of eosinophilia. Memórias do Instituto Oswaldo Cruz Rio de Janeiro 92, II:S109-14.

Gaballah, M, El-Gilany, A, El-Shazly, AM, Motawea, SM, 2001: Control of schistosomiasis in a rural area by a new safe effective herbal treatment. J. Environ. Sci., 21: 63-84.

Gundamaraju, R, Singla, RK, Vemuri, RC, Sekaran, SD, 2015: Functional correlation of medicinal chemistry and Entamoeba histolytica treatment: An emphasis on the past, present and future chemotherapy. Mini Rev. Med. Chem. 15, 3:211-9

Hamzah, Z, Petmitr, S, Mungthin, M, Leelayoova, S, Petmitr, PC, 2006: Differential detection of Entamoeba histolytica, Entamoeba dispar and Entamoeba moshkovskii by a singleround PCR assay. J. Clin. Microbiol. 44, 9:3196200.

Haridy, FM, EI Garhy, MF, Morsy, TA, 2003: The efficacy of Mirazid (Commiphora molmol) against fascioliasis in Egyptian sheep. J. Egypt. Soc. Parasitol. 33, 3:917-24.

Haridy, FM, El Garhy, MF, Morsy, TA, 2006: Some parasitic flukes infecting farm animals in Al-Santa Center, Gharbia Governorate, Egypt. J. Egypt. Soc. Parasitol. 36, 1:259-64.

Hegab, MHA, Hassan, RM, 2003: Role of circulating Fasciola antigens and IGG4 isotype in assessment of cure from fascioliasis. J. Egypt. Soc. Parasitol. 33, 3:561-70.

Iqbal, M, Ashraf, M, Jamil, A, 2006: Seed enhancement with cytokinins: Changes in growth and grain yield in salt stressed wheat plants. Plant Growth Reg. 50:29-39.

Ishikawa, N, Goyal, PK, Mahida, YR, Li, KF, Wakelin, D, 1998: Early cytokine responses during intestinal parasitic infections. Immunol. 93:257-63.
Iyer, LR, Singh, N, Verma, AK, Paul, J, 2014: Differential expression and immunolocalization of antioxidant enzymes in Entamoeba histolytica isolates during metronidazole stress. Biomed. Res. Int. 2014:704937

Kuk, S, Yazar, S, Cetinkaya, U, 2012: Stool sample storage conditions for the preservation of Giardia intestinalis DNA. Mem. Inst. Oswaldo Cruz. 107, 8:965-8.

Khairnar, K, Parija, SC, 2007: A novel nested multiplex polymerase chain reaction (PCR) assay for differential detection of Entamoeba histolytica, E. moshkovskii and E. dispar DNA in stool samples. BMC Microbiol. 24, 7:47-52.

Kirkwood, BR, 1992: Essentials of Medical Statistics. Blackwell Scientific Publications.

Lean, IS, McDonald, V, Pollok, RC, 2002: The role of cytokines in the pathogenesis of Cryptosporidium infection. Curr. Opin. Infect. Dis. 15, 3:229-34.

Lemar, KM, Turner, MP, Lioyd, D, 2002: Garlic (Allium sativum) as an anti-Candida agent: A comparison of the efficacy of fresh garlic and freeze-dried extracts. J. Appl. Microbiol. 93: 398-405.

Lin, D, Shkedy, Z, Yekutieli, D, Amaratunga D, Bijnens L, 2010: Modeling Dose-response Microarray Data in Early Drug Development Experiments Using R. Springer.

Lucey, DR, Clerici, M, Shearer, GM, 1996: Type 1 and type 2 cytokine dysregulation in human infectious, neoplastic, and inflammatory diseases. Clin. Microbiol. Rev. 9:532-62.

Massoud, AM, Soliman, AS, El-Alquamy, HE M, Salama, OM, 1998: Evaluation of molluscicidal activity of Commiphora molmol. Proceed. $7^{\text {th }}$ Conf. Egypt. Soc. Infect. Cont., October, 2729, Cairo, Egypt.

Massoud, AM, Fawzy, SM, Salama, OM, 2000: Laboratory studies on the molluscicidal and cercaricidal activities Commiphora molmol. Egypt. J. Aquat. Biol. Fish 4, 2:251-66.

Massoud, AM, El-Sissi, S, Osama, O, Massoud, A, 2001a: Preliminary study of therapeutic efficacy of a new fascolicidal drug derived from Commiphora molmol (Myrrh). Am. J. Trop. Med. Hyg. 65, 2:96-9.

Massoud, AM, El-Gilany, A, Motawea, SM, El-Shazly, A, Gaballah, M, 2001b: Effectiveness and safety of a new cestodicidal herbal drug. J. Environ. Sci. 21:91-120.

Massoud, AM, Motawea, SM, El-Gilany, A, El-Shazly, A, Sitten, A, et al, 2001c: Mirazid, a new herbal treatment highly effective against intestinal nematodes. A study carried out under 
field conditions in rural Egypt. J. Environ. Sci. 21:121-38.

Massoud, AM, Morsy, TA, Haridy, FM, 2003: Treatment of Egyptian dicrocoeliasis in man and animals with Mirazid. J. Egypt. Soc. Parasitol. 33, 2:437-42.

Massoud, AM, El-Shazly, AM, Awad, SE, Morsy, ATA, Morsy, TA, 2006: New trends in diagnosis and treatment of chronic intestinal strongyloidiasis stercoralis in Egypt in patients. J. Egypt. Soc. Parasitol. 36, 3:827-44.

Massoud, A, Hafez, AO, Abdel-Gawad, A, ElShazly, A, Morsy, TA, 2008: Mirazid alone or combined with paromomycin in treating cryptosporidiosis parvum in immunocompetent hospitalized patients. J. Egypt. Soc. Parasitol. 38, 1: 399-418.

Matowicka-Karna, J, Dymicka-Piekarska, V, Kemona, H, 2009: IFN-gamma, IL-5, IL-6 and $\mathrm{IgE}$ in patients infected with Giardia intestinalis. Folia Histochemica et Cytobiologica/ Polish Academy of Sciences 47:93-7.

McConville, M, Brennan, GP, Flanagan, A, Hanna, REB, Edgar, HWJ, et al, 2009: Surface changes in adult Fasciola hepatica following treatment in vivo with the experimental fasciolicide, compound alpha. Parasitol Res. 105:757-67.

McDonald, V, 2000: Host cell-mediated responses to infection with Cryptosporidium. Parasit. Immunol. 22:597-604.

Meaney, M, Fairweather, I, Brennan, GP, McDowell, LSL, Forbes, AB, 2003: Fasciola hepatica: effects of the fasciolicide clorsulon in vitro and in vivo on the tegumental surface, and a comparison of the effects on young- and oldmature flukes. Parasitol. Res. 91:238-50.

Morsy, TA, Salem, HS, Haridy, FM, Rifaat, MA, Abo-Zenadah, NYA, et al, 2005: Farm animals' fascioliasis in Ezbet El-Bakly (Tamyia Center) Al-Fayoum Governorate J. Egypt. Soc. Parasitol. 35, 3:825-32.

-9 .
Petry, F, Jakobi, V, Tessema, TS, 2010: Host immune response to Cryptosporidium parvum infection. Exp. Parasitol. 126:304

Riad, NHA, Taha, HA, Mahmoud, YI, 2009: Effects of garlic on albino mice experimentally infected with Schistosoma mansoni: A parasitological and ultrastructural study. Trop. Biomed. 26:40-50.

Sanderson, EW, Redford, KH, Vedder, A, Coppolillo, PB, Ward, SE, 2002: A conceptual model for conservation planning based on landscape species requirements. Landscape and Urban Planning 58:41-56.

Sen, A, Chatterjee, NS, Akbar, MA, Nandi, N, Das, P, 2007: The 29-kilodalton thiol-dependent per-oxidase of Entamoeba histolytica is a factor involved in pathogenesis and survival of the parasite during oxidative stress. Eukaryotic Cell 6, 4:664-73.

Tessema, TS, Schwamb, B, Lochner, M, Forster, I, Jakobi, V, Petry, F, 2009: Dynamics of gut mucosal and systemic Th1/Th2 cytokine responses in interferon-gamma and interleukin-12 p40 knock-out mice during primary and challenge Cryptosporidium parvum infection. Immunobiol. 214: 454-66.

Touil-Boukoffa, C, Sanceau, J, Tayebi, B, Wietzerbin, J, 1997: Relationship among circulating interferon, tumor necrosis factor alpha, and interlekin-6 and serologic reaction against parasitic antigen in human hydatidosis. J. Interferon Cytok. Res. 17:211-7.

Wallis, A, 1967: Textbook of Pharmacognosy. Churchill Livingston, London.

Wu, X, Gowda, NM, Gowda, DC, 2015: Phagosomal acidification prevents macrophage inflammatory cytokine production to malaria, and dendritic cells are major source at early stages of infection: implication for malaria protective immunity development. J. Biol. Chem. 290, 38: 23135-47. 